\title{
A STUDY OF METHOD DEVELOPMENT, VALIDATION AND FORCED DEGRADATION FOR SIMULTANEOUS QUANTIFICATION OF CABOZANTINIB AND NIVOLUMAB IN BULK AND PHARMACEUTICAL DOSAGE FORM BY RP-HPLC
}

\author{
GOPINATH K, YANADIRAO M, PAVANI Y, SUBBA RAO M* \\ Department of Chemistry, Acharya Nagarjuna University, Nagarjuna Nagar, Andhra Pradesh, India. Email: subbraom.1808@gmail.com \\ Received: 09 August 2018, Revised and Accepted: 26 September 2018
}

\section{ABSTRACT}

Objective: The present paper describes a simple, accurate, and precise reversed-phase high-performance liquid chromatography (HPLC) method for rapid and simultaneous quantification of cabozantinib (CZT) and nivolumab (NVM) in bulk and pharmaceutical dosage form.

Methods: The chromatographic separation was achieved on Luna C18 $(150 \mathrm{~mm} \times 4.6 \mathrm{~mm}, 3.5 \mu \mathrm{m})$. Mobile phase contained a mixture of $0.1 \%$ orthophosphoric acid and acetonitrile in the ratio of $50: 50 \mathrm{v} / \mathrm{v}$, flow rate $1.0 \mathrm{ml} / \mathrm{min}$, and ultraviolet detection at $222 \mathrm{~nm}$.

Results: The proposed method shows a good linearity in the concentration range of 20-300 $\mu \mathrm{g} / \mathrm{ml}$ for CZT and 5-75 $\mu \mathrm{g} / \mathrm{ml}$ for NVM under optimized conditions. Precision and recovery study results are in between 98 and 102\%. In the entire robustness conditions, percentage relative standard deviation is $<2.0 \%$. Degradation has minimum effect in stress condition and solutions are stable up to $24 \mathrm{~h}$.

Conclusion: This method is validated for different parameters such as precision, linearity, accuracy, limit of detection (LOD), limit of quantification (LOQ), ruggedness, robustness, and forced degradation study were determined according to the International Conference of Harmonization (ICH) Q2B guidelines. All the parameters of validation were found to be within the acceptance range of ICH guidelines. Since there is no HPLC method reported in the literature for the estimation of CZT and NVM in pharmaceutical dosage forms, there is a need to develop quantitative methods under different conditions to achieve improvement in sensitivity, selectivity, etc.

The author declares the interest to develop a validation and forced degradation for simultaneous quantification of CZT and NVM.

Keywords: Cabozantinib, Nivolumab, Reversed-phase high-performance liquid chromatography.

(C) 2019 The Authors. Published by Innovare Academic Sciences Pvt Ltd. This is an open access article under the CC BY license (http://creativecommons. org/licenses/by/4. 0/) DOI: http://dx.doi.org/10.22159/ajpcr.2019.v12i2.29013

\section{INTRODUCTION}

Cabozantinib (CZT) is a medication used to treat medullary thyroid cancer [1] and a second line treatment for renal cell carcinoma [2] among others. It is a small molecule [3] inhibitor of the tyrosine kinesis [4] c-Met $[5,6]$ and vascular endothelial growth factor receptor 2 [7], and also inhibits AXL [8] and RET [9]. It was discovered and developed by Evelix's [10] included in the study.

Nivolumab (NVM) marketed as Opdivo, is a medication used to treat cancer [11]. It is used as a first-line treatment for inoperable or metastatic melanoma [12] in combination with ipilimumab [13] if the cancer does not have a mutation in BRAF as a second-line treatment following treatment with ipilimumab and if the cancer has a mutation in BRAF, with a BRAF inhibitor [14] as a second-line treatment for squamous non-small cell lung cancer [15] and as a second-line treatment for renal cell carcinoma [2]. It had not been tested in pregnant women but based on the mechanism of action and animal studies, is probably toxic to the baby, it is not known if it is secreted in breast milk. Side effects include severe immunerelated inflammation of the lungs, colon, liver, kidneys, and thyroid, and there are effects on skin, central nervous system [16], the heart, and the digestive system [17]. It is a human IgG4 [18] anti-PD-1 [19] monoclonal antibody [20]. NVM works as checkpoint inhibitor [21] blocking a signal that would have prevented activated T-cells [22] from attacking the cancer, thus allowing the immune system to clear the cancer. It was discovered at Medarex [23], developed by Medarex and Ono pharmaceutical, and brought to market by Bristol-Myers Squibb [24] and Ono.
To date, there is no literature for current drugs of CZT and NVM for highperformance liquid chromatography (HPLC) and spectrophotometry. Hence, we have to develop stability-indicating simultaneous estimation and forced degradation of CZT and NVM in bulk and pharmaceutical dosage form.

\section{METHODS}

\section{Instrumentation}

The analysis was performed on Water Alliance e-2695 chromatographic system equipped with a quaternary pump and photodiode array detector (PDA) detector-2996. Chromatographic software empower-2.0 was used for data collection.

\section{Chemicals and reagents}

Acetonitrile (HPLC grade), orthophosphoric acid (OPA) (HPLC grade), and water (HPLC grade) were purchased from Merck (India) Ltd., Worli, Mumbai, India. Active pharmaceutical ingredients (APIs) of CZT and NVM reference standards were produced from Glenmark Pharmaceuticals Private Ltd., Mumbai, India.

\section{Chromatographic conditions}

Chromatographic analysis was done using isocratic elution, mobile phase in the ratio of acetonitrile:buffer $(0.1 \%$ OPA) $(50: 50 \mathrm{v} / \mathrm{v})$ was filtered through $0.45 \mu$ membrane filter paper. The flow rate of the mobile phase was monitored at $1.0 \mathrm{ml} / \mathrm{min}$ and eluents were detected at $222 \mathrm{~nm}$. By injecting the volume $10 \mu \mathrm{l}$ with a run time $10 \mathrm{~min}$. 
Selection of wavelength

Using PDA detector, the absorption spectra of the solution of two drugs were scanned in the ultraviolet region 200-400nm spectra shown in Fig. 1, the spectra of the CZT and NVM shown at different $\lambda_{\text {max }}$, namely 245.0 and $273.3 \mathrm{~nm}$, respectively. By overlay of the two spectra combined at $222 \mathrm{~nm}$ was selected as detection wavelength for HPLC chromatographic method.

\section{Preparation of standard solution}

About $200 \mathrm{mg}$ of CZT and $50 \mathrm{mg}$ of NVM working standard taken into a $100 \mathrm{ml}$ volumetric flask. Add $70 \mathrm{ml}$ of mobile phase sonicated for 10 min to dissolve and makeup to the mark with mobile phase. Further, diluted each $5 \mathrm{ml}$ of above two solutions to $50 \mathrm{ml}$ with mobile phase.

\section{Preparation of sample solution}

Weigh 20 tablets and take the one tablet equivalent weight. Crush the 20 tablets into powder form, take $600 \mathrm{mg}$ of sample into a $100 \mathrm{ml}$ volumetric flask, and add $70 \mathrm{ml}$ mobile phase sonicated for $30 \mathrm{~min}$ after that makeup to the mark with mobile phase. Further, dilute $5 \mathrm{ml}$ of above solution to $50 \mathrm{ml}$ volumetric flask make up to mark with mobile phase. Filter through $0.45 \mu$ nylon syringe filter.

\section{Validation}

System suitability

As per the test method, the standard solutions were prepared and injected into HPLC system from which the evaluated system suitability parameters are found to be within the limits.

\section{Linearity}

The ability of the method to produce results those are directly or indirectly proportional to the concentration of the analyst in samples within the limits.

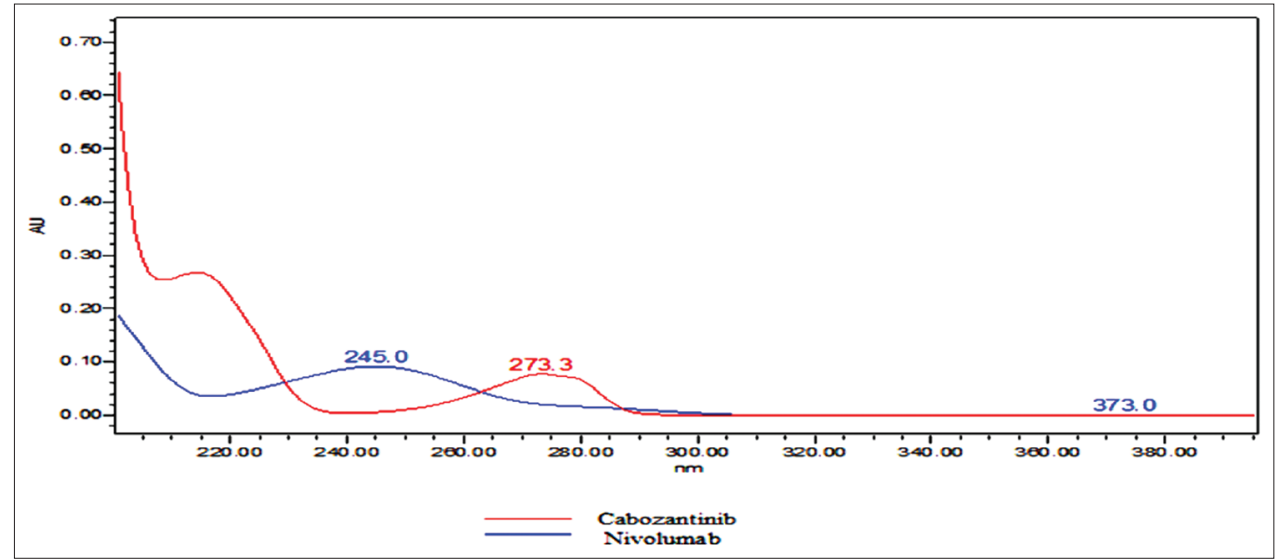

Fig. 1: Photodiode array detector spectra for cabozantinib and nivolumab

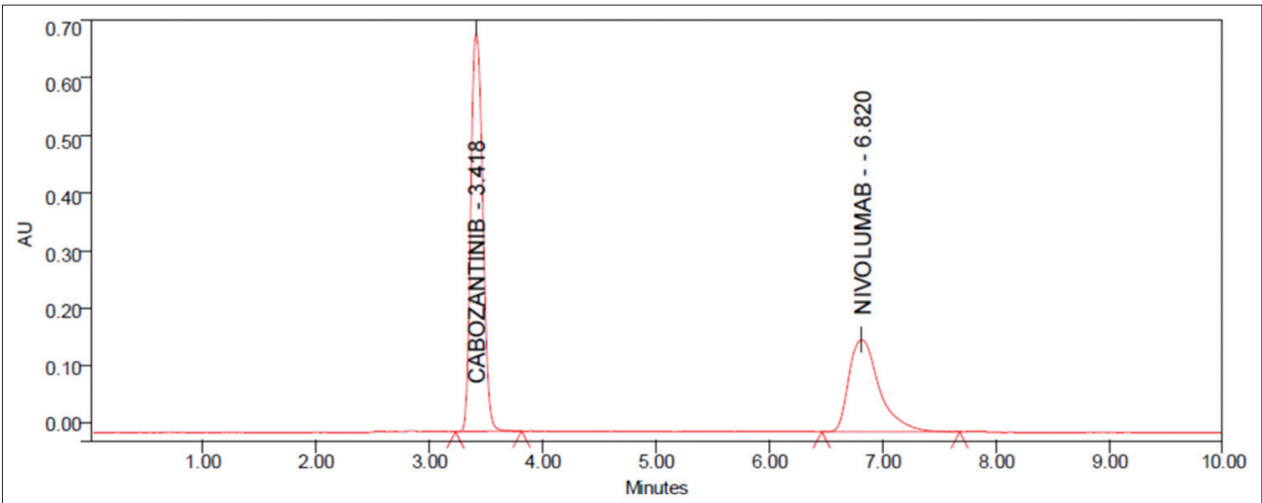

Fig 2: Typical standard chromatogram for carbozamtinib and nivolumab

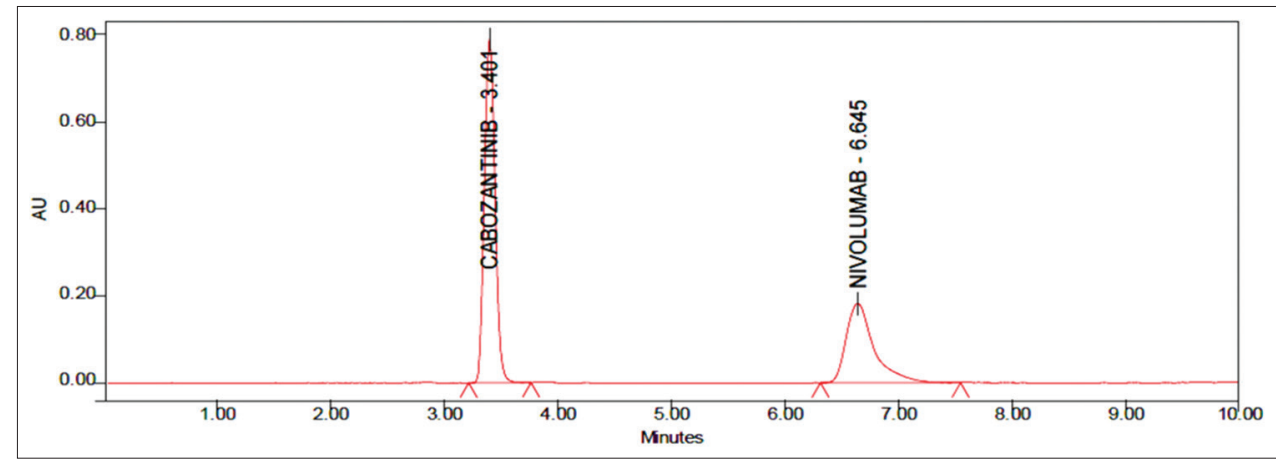

Fig. 3: Typical sample chromatogram for carbozantinib and nivolumab 


\section{Precision}

The degree of the closeness of agreement among individual test results when a method is applied to multiple samplings of a homogeneous sample. It is a measure of either the degree of reproducibility (agreement under different conditions) or repeatability (agreement under the same conditions) of the method.

\section{Accuracy}

The closeness of results was obtained by a method to the true value. It is a measure of the exactness of the method.

\section{Limit of detection (LOD) and limit of quantification (LOQ)}

The detection limit and quantification limit for each analyte were determined based on a signal-to-noise concept, as the lowest concentration at which signal-to-noise ratio between 3 or 2:1 and $10: 1$, respectively, with defined precision and accuracy under the given experimental conditions.

\section{Stability}

Standard and the sample solutions were subjected to $24 \mathrm{~h}$ stability studies at room temperature (RT) and $2-8^{\circ} \mathrm{C}$. The stability of these solutions was studied and observed for changes in the area and retention time of the peaks which were then compared with the pattern of the chromatogram of the freshly prepared solution.

\section{Robustness}

Robustness of the method was studied by slightly changes in experimental conditions such as flow rate and organic composition.

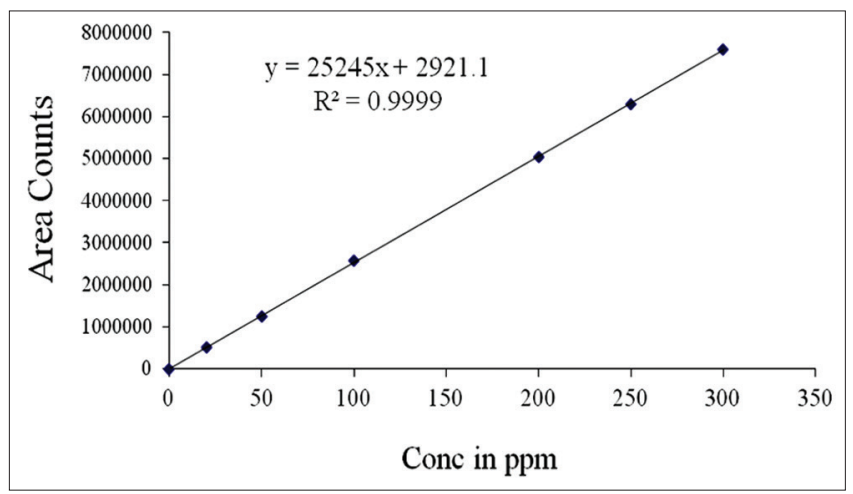

Fig. 4: Linearity plot for nivolumab
Robustness on performed same instrument with different chromatic conditions.

\section{Ruggedness}

Ruggedness of the method was studied using different source of analysts, instruments, and columns with same experimental conditions.

\section{RESULTS AND DISCUSSION}

\section{Method validation}

In this method, system suitability, linearity, precision, accuracy, robustness, LOD, LOQ forced degradation, and stability are validated for the selected CZT and NVM drugs.

\section{System suitability}

$200 \mu \mathrm{g} / \mathrm{ml}$ of CZT and $50 \mu \mathrm{g} / \mathrm{ml}$ of NVM was prepared and injected into the system. The retention times of CZT and NVM were found to be 3.418 and $6.820 \mathrm{~min}$, respectively. Resolution of the NVM was 8.36 from the CZT. The number of theoretical plate counts for CZT and NVM was 8560 and 4836, respectively. Tailing factor for CZT and NVM was 0.46 and 0.38 , respectively. All the parameters found to be within the limit.

\section{Linearity}

Linearity of the method was evaluated by preparing a standard solution containing $200 \mu \mathrm{g} / \mathrm{ml}$ of CZT and $50 \mu \mathrm{g} / \mathrm{ml}$ of NVM (100\% targeted level of the assay concentration). Sequential dilutions were performed to give solutions at $10,25,50,100,125$, and $150 \%$ of the target concentrations. These were injected and peak areas used to plot calibration curves against the concentration. The correlation coefficient values of these three analytes were 0.999 . The results are shown in Table 1.

\section{LOD and LOQ}

LOD and LOQ are the minimum concentration level at which the analyte can be reliably detected, quantified using the standard formulas (3.3 times $\sigma / \mathrm{s}$ and 10 times $\sigma / \mathrm{s}$ for LOD and LOQ respectively). LOD values for CZT and NVM were 0.2 and $0.05 \mu \mathrm{g} / \mathrm{ml}$ and s/n values are 4 and 7, respectively. LOQ values for CZT and NVM were 0.66 and $0.165 \mu \mathrm{g} / \mathrm{ml}$ and $\mathrm{s} / \mathrm{n}$ values are 25 and 28 , respectively.

\section{Precision}

Method precision was investigated by the analysis of six separately prepared samples of the same batch. From this, six separate samples solution was injected and the peak areas obtained used to calculate mean and percentage relative standard deviation (\%RSD) values. The present method was found to be precise as $\% \mathrm{RSD}$ of $<2 \%$, and also, the percentage assay values were closed to be $100 \%$. The results are given

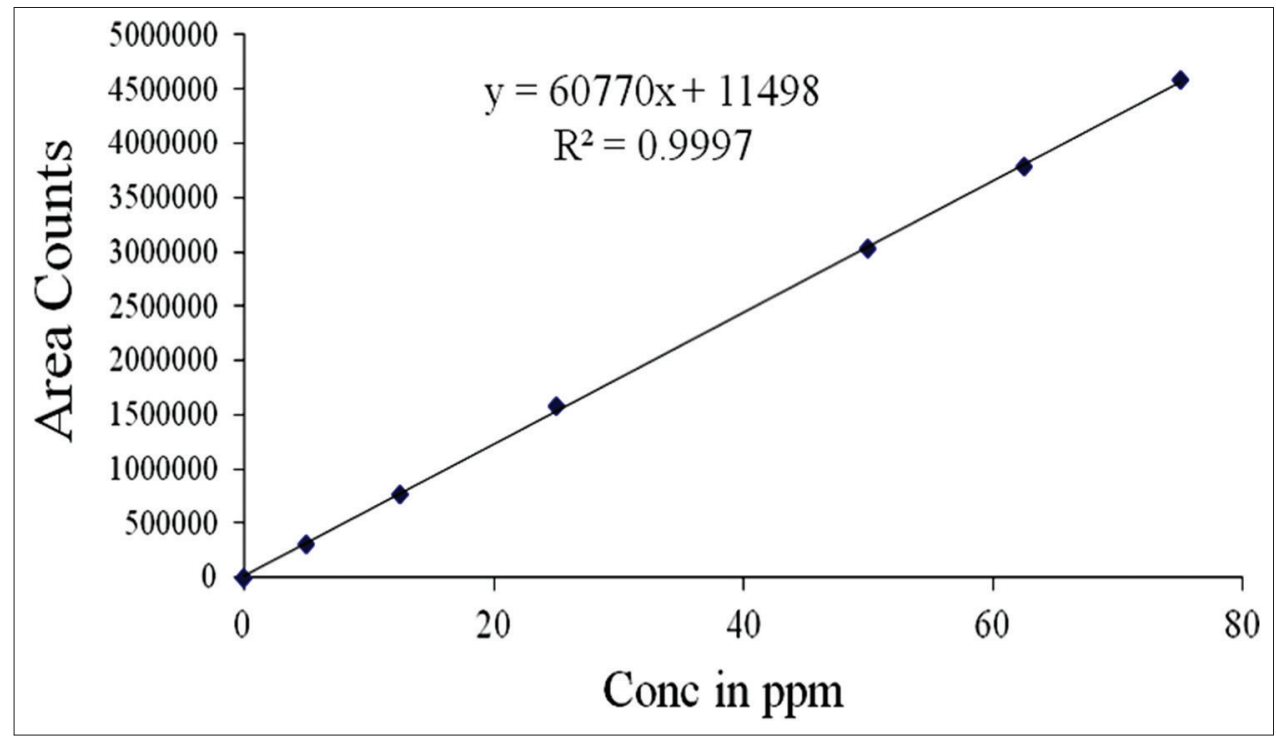

Fig. 5: Linearity plot for nivolumab 
Table 1: Linearity study results

\begin{tabular}{llll}
\hline Analyte & $\begin{array}{l}\text { Linearity } \\
\text { range }\end{array}$ & $\begin{array}{l}\text { Equation of } \\
\text { calibration curve }\end{array}$ & $\begin{array}{l}\text { Correlation } \\
\text { coefficient }\end{array}$ \\
\hline $\mathrm{CZT}$ & $20-300 \mu \mathrm{g} / \mathrm{ml}$ & $\mathrm{Y}=25245 \mathrm{x}+2921$ & 0.999 \\
$\mathrm{NVM}$ & $5-75 \mu \mathrm{g} / \mathrm{ml}$ & $\mathrm{Y}=60770 \mathrm{x}+11498$ & 0.999 \\
\hline
\end{tabular}

CZT: Cabozantinib, NVM: Nivolumab

Table 2: Method precision results

\begin{tabular}{llll}
\hline Analyte & Amount present & \% assay (mean) & \%RSD of assay \\
\hline CZT & $200 \mu \mathrm{g} / \mathrm{ml}$ & 100.32 & 0.45 \\
NVM & $50 \mu \mathrm{ml}$ & 100.18 & 0.21 \\
\hline
\end{tabular}

CZT: Cabozantinib, NVM: Nivolumab, \%RSD: Percentage relative standard deviation

Table 3: Accuracy (recovery) study results

\begin{tabular}{lllll}
\hline $\begin{array}{l}\text { Percentage of target } \\
\text { concentration }\end{array}$ & $\begin{array}{l}\text { CZT (\% } \\
\text { recovery) }\end{array}$ & $\begin{array}{l}\text { CZT } \\
\text { (\%RSD) }\end{array}$ & $\begin{array}{l}\text { NVM (\% } \\
\text { recovery) }\end{array}$ & $\begin{array}{l}\text { NVM } \\
\text { (\%RSD) }\end{array}$ \\
\hline 50 & 100.41 & 0.13 & 100.48 & 0.51 \\
100 & 100.57 & 0.26 & 100.36 & 0.63 \\
150 & 100.21 & 0.53 & 100.78 & 1.11 \\
\hline
\end{tabular}

CZT: Cabozantinib, NVM: Nivolumab, \%RSD: Percentage relative standard deviation

in Table 2.

\section{Accuracy}

Accuracy was determined by recovery studies which were carried out in three different concentrations levels $(50 \%, 100 \%$, and 150\%). APIs with concentration of 100,200 , and $300 \mu \mathrm{g} / \mathrm{ml}$ of CZT and 25, 50, and $75 \mu \mathrm{g} / \mathrm{ml}$ of NVM were prepared. As per the test method, the test solution was injected three preparations each spike level and the assay was performed. The percentage of recovery values was found to be in the range of $100.14-100.26 \%$ of CZT and $100.54-100.72 \%$ of NVM. RSD values were found to be $<2 \%$. The results are given in Table 3 .

\section{Ruggedness}

Ruggedness of the method was studied and showed that chromatographic patterns did not significantly change when different HPLC systems, analysts, and columns. The value of percentage of RSD was below $2 \%$ and exhibits the ruggedness of the developed method.

\section{Robustness}

Robustness of the method found to be \%RSD should be $<2 \%$. Slight variations were done in the optimized method parameters such as flow rate $( \pm 20 \%)$ and organic content in mobile phase $( \pm 5 \%)$. The results are given in Table 4 .

\section{Stability}

Stability of standard and sample solutions is studied initial to $24 \mathrm{~h}$ in stored $\mathrm{RT}$ and $2-8^{\circ} \mathrm{C}$. These solutions are analyzed initial to $24 \mathrm{~h}$ at different time intervals and results were recorded. The \% deviation should not be more than $5.0 \%$. There are no effects in storage conditions for CZT and NVM drugs. The results are shown in Table 5.

\section{Forced degradation}

Forced degradation conditions such as acidic, basic, oxidative, reduction, thermal, hydrolysis, and photolytic stresses were attempted as per the International Conference of Harmonization (ICH) guidelines Q2B. There is an effect of assay results. The results are shown in Table 6.

\section{CONCLUSION}

CZT and NVM are two drugs reported as novel and method is novel and is very strong discussion for the developed method in their validation. This method described the quantification of CZT and NVM in bulk and
Table 4: Robustness results

\begin{tabular}{lllll}
\hline $\begin{array}{l}\text { Drug } \\
\text { name }\end{array}$ & $\begin{array}{l}\text { Flow plus } \\
(\mathbf{1 . 2} \mathbf{~ m l} / \mathbf{m i n}) \\
\text { (\%RSD) }\end{array}$ & $\begin{array}{l}\text { Flow minus } \\
\text { (0.8 } \mathbf{~ m l} / \mathbf{m i n}) \\
\text { (\%RSD) }\end{array}$ & $\begin{array}{l}\text { Organic } \\
\text { plus (55:45) } \\
\text { (\%RSD) }\end{array}$ & $\begin{array}{l}\text { Organic } \\
\text { minus (45:55) } \\
\text { (\%RSD) }\end{array}$ \\
\hline CZT & 0.36 & 0.36 & 0.42 & 0.46 \\
NVM & 0.92 & 0.78 & 0.59 & 0.36 \\
\hline
\end{tabular}

CZT: Cabozantinib, NVM: Nivolumab, \%RSD: Percentage relative standard deviation

Table 5: Stability results

\begin{tabular}{lllll}
\hline Stability & $\begin{array}{l}\text { CZT \% } \\
\text { assay }\end{array}$ & \% difference & $\begin{array}{l}\text { NVM \% } \\
\text { assay }\end{array}$ & \% difference \\
\hline Initial & 100.82 & 0.00 & 100.75 & 0.00 \\
$12 \mathrm{~h}$ & 100.75 & 0.07 & 100.58 & 0.17 \\
$18 \mathrm{~h}$ & 100.52 & 0.30 & 100.42 & 0.33 \\
$24 \mathrm{~h}$ & 100.36 & 0.46 & 100.25 & 0.50 \\
\hline
\end{tabular}

CZT: Cabozantinib, NVM: Nivolumab

Table 6: Forced degradation results

\begin{tabular}{lllll}
\hline Degradation & $\begin{array}{l}\text { CZT } \\
\text { (\% assay) }\end{array}$ & $\begin{array}{l}\text { \% of } \\
\text { degradation }\end{array}$ & $\begin{array}{l}\text { NVM } \\
\text { (\% assay) }\end{array}$ & $\begin{array}{l}\text { \% of } \\
\text { degradation }\end{array}$ \\
\hline Control & 100.5 & 0.00 & 100.45 & 0.00 \\
Acid & 87.32 & 13.18 & 85.63 & 14.82 \\
Alkali & 90.48 & 10.02 & 90.32 & 10.13 \\
Peroxide & 83.68 & 16.82 & 83.14 & 17.31 \\
Reduction & 95.31 & 5.19 & 89.68 & 10.77 \\
Thermal & 75.36 & 25.14 & 72.68 & 27.77 \\
Photolytic & 89.54 & 10.96 & 87.98 & 12.47 \\
Hydrolysis & 84.14 & 15.96 & 83.68 & 16.77 \\
\hline
\end{tabular}

CZT: Cabozantinib, NVM: Nivolumab

pharmaceutical formulation as per the ICH guidelines. The developed method was found to be accurate, precise, linear, and reliable. The advantage lies in the simplicity of sample preparation and economically fewer reagents were used. In addition, two compounds are eluted within $10 \mathrm{~min}$. The proposed HPLC method was suitable resolution to precise quantification of the compounds. Statistical analysis of the experimental result indicates that the precision and reproducibility data are satisfactory. The developed chromatographic method can be effectively applied for routine analysis in drug research.

\section{AUTHORS' CONTRIBUTION}

M. Subbarao has provided the design, intellectual content, innovations, and protocol for conducting the experiment along with mentorship. $\mathrm{K}$. Gopinath has majorly performed the analysis in laboratory, literature collection, and sincerely authored the article. M. Yanadirao has a minor role in the conducting the analysis in the laboratory, analysis of obtained data, and calculating the analysis data. Y. Pavani has a minor role in the review the data.

\section{CONFLICTS OF INTEREST}

The authors declare that there no conflicts of interest regarding the publication of this article.

\section{REFERENCES}

1. Hu MI, Vassilopoulou-Sellin R, El-Naggar A. Thyriod and parathyroid cancers in cancer management. A multidisciplinary approach. Wayback Machine 2008;18:941-8.

2. Curti B, Jana B, Mandal RN. Renal cell carcinoma. Medscape 2014;14:248-62.

3. Bruce A, Bray D, Lewis J, Raff M. Molecular biology of the cell. Graland Sci 1996;6:1-10

4. Hanks SK, Quinn AM, Hunter T. The protein kinase family: Conserved features and deduced phylogeny of the catalytic domains. Science 
1988;241:42-52.

5. Bottaro DP, Rubin JS, Faletto DL, Chan AM, Kmiecik TE, Vande Woude GF, et al. Identification of the hepatocyte growth factor receptor as the c-met proto-oncogene product. Science 1991;251:802-4.

6. Galland F, Stefanova M, Lafage M, Birnbaum D. Localization of the 5' end of the MCF2 oncogene to human chromosome 15q15-q23. Cytogenet Cell Genet 1992;60:114-6.

7. Holmes K, Roberts OL, Thomas AM, Cross MJ. Vascular endothelial growth factor receptor-2: Structure, function, intracellular signalling and therapeutic inhibition. Cell Signal 2007;19:2003-12.

8. O’Bryan JP, Frye RA, Cogswell PC, Neubauer A, Kitch B, Prokop C, et al. Axl, a transforming gene isolated from primary human myeloid leukemia cells, encodes a novel receptor tyrosine kinase. Mol Cell Biol 1991;11:5016-31.

9. Ellis A, Dryden W, Bond FW. Reason and Emotion in Psychotherapy: Comprehensive Method of Treating Human Disturbances. New York: Carol Publishing Group; 1994.

10. Carthy M, Alice A, et al. Evelix's integrated drug-discovery and development platform for human therapeutics. Chem Biol 2005;12:407-8.

11. World Health Organization. WHO Drug information. Vol. 26. North York: World Health Organization; 2012. p. 2.

12. National Cancer Institute. Melanoma Treatment-for Health Professionals. United States: National Cancer Institute; 2015.

13. Yervoy, ipilimumab-Product profile-Bio Century. Bio Century Online
Intelligence. New York: Bio Century Publications; 2012.

14. Johnson DB, Peng C, Sosman JA. Nivolumab in melanoma: Latest evidence and clinical potential. Ther Adv Med Oncol 2015;7:97-106.

15. Sundar R, Cho BC, Brahmer JR, Soo RA. Nivolumab in NSCLC: Latest evidence and clinical potential. Ther Adv Med Oncol 2015;7:8596.

16. Farlex. Partner Medical Dictionary. Huntingdon valley: Farlex; 2012.

17. Large Intestine. Encyclopedia Britannica. Chicago: WENTWORTH Press; 2016.

18. Junqueria LC, Carneiro J. Basic Histology. Brazil: Mc Graw-Hill; 2003.

19. Francisco LM, Sage PT, Sharpe AH. The PD-1 pathway in tolerance and autoimmunity. Immunol Rev 2010;236:219-42.

20. Harry V.Galboin, Cytochrome P450 mediated drug and carcinogen metabolism using monocloanl antibodies. Avaliable from: https://home. ccr.cancer.gov/metabolism/hvgccr.htm

21. Pardoll DM. The blockade of immune checkpoints in cancer immunotherapy. Nat Rev Cancer 2012;12:252-64.

22. Alberts B, Johnson A, Lewis J, Raff M, Roberts K, Walter P. Molecular Biology of the Cell. New York: Graland Science; 2002. p. 1367.

23. Couzin-Frankel J. Breakthrough of the year 2013. Cancer immunotherapy. Science 2013;342:1432-3.

24. US SEC, Form 10-K Bristol-Myers Squibb Company. U.S. Securities and Exchange Commission. Bristo-Myers squibb company, Newyork. 